\title{
Pengembangan Model Pembelajaran Natural Messy Play sebagai Optimalisasi Kecerdasan Kinestetik Anak
}

\author{
Aulia Annisa ${ }^{1 凶}$ \\ Pendidikan Islam Anak Usia Dini, Sekolah Tinggi Agama Islam Syekh H. Abdul Halim \\ Hasan Al-Ishlahiyah Binjai \\ DOI: $\underline{10.31004 / o b s e s i . v 6 i 1.914}$
}

\begin{abstract}
Abstrak
Penelitian ini bertujuan untuk menganalisis, mengembangkan, dan menguji efektifitas dari model pembelajaran Natural Messy Play dalam meningkatkan kecerdasan kinestetik anak usai 4-5 tahun. Penelitian ini menggunakan jenis research and development dengan subjek uji coba sebanyak 120 orang anak usia 4-5 tahun se-Kabupaten Sleman. Pengumpulan data menggunakan teknik observasi, wawancara, dan angket dengan desain equivalent time series design. Efektivitas model pembelajaran Natural Messy Play dianalisis menggunakan uji Kruskal Wallis dengan taraf signifikansi 0,05. Penelitian pengembangan ini memperoleh hasil berupa: (1) Natural Messy Play dinyatakan sebagai sebuah model pembelajaran berdasarkan karakteristik sintaks, system sosial, sistem pendukung, dan peran guru; (2) model pembelajaran Natural Messy Play dinyatakan layak digunakan dengan kategori sangat baik; (3) model pembelajaran Natural Messy Play dinyatakan efektif digunakan sebagai optimalisasi kecerdasan kinestetik anak usia 4-5 tahun se-Kabupaten Sleman berdasarkan analisis Hasil uji statistik Kruskal Wallis yang memperoleh nilai sig. 0,00.
\end{abstract}

Kata Kunci: model pembelajaran; natural messy play; kecerdasan kinestetik.

\begin{abstract}
This research aimed to analyze, improve and identify the effectiveness of Natural Messy Play in improving kinesthetic intelligence of 4- to 5-year-old children. This was research and development with 120 subjects of children from 4- to 5-year-old in Sleman. The data was collected by conducting observation, interview, and distributing questionnaires by equivalent time series design. The effectiveness of Natural Messy Play was analyzed by using Kruskal Wallis test in the significance level of 0.05 . The results of this research development were: (1) Natural Messy Play was expressed as a learning model based on the characteristics of syntax, social system, support system, and the role of the teacher; (2) The Natural Messy Play learning model was declared feasible to use with very good categories; (3) Natural Messy Play learning model was effective in optimalizing kinesthetic intelligence for 4-to 5-year-old children in Sleman based on the results of the Kruskal Wallis statistic test obtained the sig value 0.00.
\end{abstract}

Keywords: learning model; natural messy play; kinesthetic intelligence.

Copyright (c) 2021 Aulia Annisa

$\triangle$ Corresponding author:

Email Address : auliahamdan19@gmail.com (Binjai, Indonesia)

Received 25 November 2020, Accepted 20 December 2020, Published 2 June 2021 


\section{PENDAHULUAN}

Anak terlahir dengan ratusan milyar sel otak yang akan berkembang dan tumbuh secara optimal seiring dengan pertambahan usia. Bagian-bagian dari sel otak anak akan terhubung satu sama lain untuk membentuk jaringan-jaringan yang kuat sehingga mampu mengoptimalkan fungsi pada seluruh bagian tubuh anak. Masa usia dini merupakan masa terjadinya kematangan fungsi-fungsi fisik dan psikis yang siap merespon stimulasi yang diberikan oleh lingkungan. Masa ini juga merupakan masa untuk meletakkan dasar pertama dalam mengembangkan potensi fisik (motorik), intelektual, emosional, sosial, bahasa, seni dan moral spiritual. Jika anak terus menerus berada dalam kondisi terbatas dalam mengekspresikan diri, justru akan mematikan synaps-synap dalam otak anak yang sedang berkembang (Annisa dan Sutapa, 2019).

Tidak hanya aspek perkembangan, potensi kecerdasan yang dimiliki anak juga harus dioptimalkan agar anak tidak hanya sekedar tumbuh dan berkembang tapi juga perlahan menemukan potensi dalam dirinya. Salah satu potensi kecerdasan yang perlu dioptimalkan dengan baik adalah kecerdasan kinestetik. Hal ini dikarenakan untuk dapat tumbuh dan berkembang dengan optimal, anak membutuhkan fisik yang kuat agar dapat merealisasikan tindakan atau gerakan sesuai dengan apa yang ada didalam fikiran (Armstrong, 2009).

Senada dengan hal tersebut, (Damovska et al., 2009) menyatakan bahwa kondisi fisik yang baik memberi anak-anak energi dan kegigihan untuk aktif berpartisipasi dalam proses pembelajaran. Pengembangan motorik yang seimbang mempengaruhi secara langsung domain pengembangan yang lainnya seperti kemampuan berbicara, perkembangan kognitif, kompetensi sosial dan perkembangan emosi.

Momentum yang paling tepat untuk melatih kemampuan gerak anak melalui program aktivitas jasmani adalah pada usia antara 3-5 tahun, sebab usia tersebut merupakan usia kritis untuk belajar sesuatu. semakin banyak pengalaman yang dilakukan dimasa kecil, semakin besar pula peluang anak untuk menemukan potensi terbaiknya dibidang tertentu (Sudijandoko, 2011). Hal ini menunjukkan bahwa pada masa ini anak perlu mendapatkan pengalaman gerak yang beraneka ragam (multi lateral). Hal ini semakin diperkuat dengan pendapat Hurlock dalam (Annisa \& Sutapa, 2019) yang menyatakan bahwa masa kanakkanan adalah saat yang paling ideal untuk mempelajari keterampilan tertentu.

Fenomena yang terjadi saat ini adalah kecerdasan kinestetik pada anak usia dini mengalami kendala untuk distimulasi dikarenakan kurangnya kesempatan anak untuk bergerak dengan bebas di luar ruangan. Akibatnya, anak lebih memilih melakukan aktivitas yang tidak membutuhkan banyak gerak. Padahal kecerdasan tubuh (fisik) pada anak usia dini dapat membantu anak-anak berkembang menjadi orang dewasa yang sehat, mudah menyesuaikan diri dan penuh keyakinan (Astuti Ria, 2017).

Selain itu, Munculnya permainan instan yang akhirnya menjauhkan anak dalam berinteraksi dengan lingkungan alam menjadi penyebab kurangnya minat anak pada aktivitas fisik diluar ruangan. Budaya anak-anak terancam oleh media massa dan kelebihan produksi mainan plastik siap pakai yang tidak menuntut anak untuk bergerak. Kenyataan lain yang menjadi masalah adalah kinestetik seringkali kurang diperhatikan di sekolah. Aktivitas di sekolah lebih mengutamakan pada kegiatan yang mengasah kemampuan kognitif anak. Padahal kinestetik juga merupakan salah satu hal yang penting untuk distimulus pada tahuntahun pertama kehidupan anak.

Kecerdasan kinestetik atau kecerdasan jasmani merupakan kemampuan menggunakan seluruh tubuh dan komponennya untuk memecahkan suatu permasalahan, membuat sesuatu, atau menggunakan beberapa macam produk, dan koordinasi anggota tubuh dan pikiran untuk menyempurnakan penampilan fisik (Gardner dalam Kutz et al., 2013). Berdasarkan hasil studi pendahuluan, dari 120 anak hanya ada 25-30 anak atau sekitar $25 \%$ memiliki kecerdasan fisik yang dikatakan baik, $75 \%$ sisanya belum mampu mengembangkan kemampuan olah tubuhnya (Annisa dan Sutapa, 2019). 
Kesempatan anak untuk bergerak bebas atau bermain diluar ruangan terbatas oleh kegiatan pelajaran yang sebagian besar dilakukan di dalam ruangan. Hal ini justru sangat merugikan bagi anak karena (Widhianawati, 2011) menyebutkan bahwa pada usia 4 tahun kapasitas kecerdasan sudah mencapai 50\%. Gardner memaparkan 3 kriteria yang termasuk kedalam sebuah kecerdasan. Pertama, bentuk afasia otak yang dapat mempengaruhi kecerdasan apabila terdapat satu bagian otak yang rusak (menunjukkan multiplisitas). Kedua, cara kecerdasan berkontribusi pada evolusi umat manusia. Ketiga, sejauh mana budaya telah mengidentifikasi contoh-contoh dari kecerdasan otak tersebut (Blumenfeld, 2019).

Pemanfaatan lingkungan alam yang kurang optimal dalam mendukung stimulus kecerdasan kinestetik anak juga menghasilkan beberapa studi yang menunjukkan bahwa anak-anak zaman sekarang kekurangan keterampilan motorik yang cukup untuk mempertahankan kesehatan (Castetbon \& Andreyeva, 2012). Kecenderungan yang mengkhawatirkan ini mungkin mencerminkan perubahan dalam aktivitas maupun perilaku anak-anak dalam beberapa dekade terakhir dan mungkin mencerminkan gaya hidup yang tidak aktif serta rendahnya tingkat aktivitas fisik (Hinkley et al., 2010). Padahal, bermain di alam terutama di periode kritis dari masa kanak-kanak menjadi waktu yang sangat penting untuk mengembangkan kreativitas, pemecahan masalah, intelektual dan perkembangan emosional (Kellert, 2018).

Fenomena lainnya menunjukkan beberapa anak tidak mau bergabung bersama temannya untuk bermain atau melakukan kegiatan diluar ruangan atau lingkungan alam dikarenakan tidak ingin tubuhnya menjadi kotor. Padahal, bermain di alam terutama di periode kritis dari masa kanak-kanak menjadi waktu yang sangat penting untuk mengembangkan kreativitas, pemecahan masalah, intelektual dan perkembangan emosional (Charles \& Louv, 2009; Kivunja, 2015).

Berdasarkan beberapa masalah yang ditemukan dari hasil observasi dan penelitian terdahulu, disimpulkan bahwa kemampuan anak mengolah tubuh dalam melakukan aktivitas di lingkungan alam masih tergolong rendah. Dibutuhkan sebuah model pembelajaran yang memungkinkan anak untuk bergerak aktif tanpa menghiraukan tubuhnya akan menjadi kotor dan berantakan. Aktivitas yang memunculkan kesenangan dalam diri anak untuk bereksplorasi di lingkungan alam menggunakan tubuhnya. Maka dari itu, peneliti mengembangkan sebuah inovasi dalam model pembelajaran yang diujicobakan dalam sebuah penelitian yang berjudul "Pengembangan Model Pembelajaran Natural Messy Play sebagai Optimalisasi Kecerdasan Kinestetik Anak Usia 4-5 Tahun".

Natural Messy Play merupakan sebuah pengembangan dari Messy Play. Messy Play adalah jenis permainan menggunakan benda yang membuat anak menjadi kotor dan berantakan dalam merangsang sensor motorik halus dan motorik kasar serta keterampilan anak (Szekely, 2015). Messy Play menuntut anak-anak untuk menggunakan semua indranya dalam proses eksplorasi dan sentuhan indra yang luar biasa (Yin, L.C; Zakaria, A.R; Sulaiman, 2017). Kelemahannya, messy play menggunakan material bahan yang cukup membahayakan untuk anak seperti pasir, cat, air, adonan mainan, gloop, tanah liat, parutan kertas hingga busa cukur. Hal ini tentu akan membahayakan anak jika tidak didampingi oleh orangtua secara intens.

Maka dari itu, peneliti membuat sebuah inovasi pembelajaran yang memungkinkan anak melakukan aktivitas bermain dengan meminimalisir resiko berbahaya. Model pembelajaran Natural Messy Play diciptakan sebagai solusi untuk mengatasi keterbatasan model pembelajaran dalam mendukung terstimulusnya kecerdasan kinestetik anak sehingga anak dapat mengoptimalkan keterampilan hidup dan menyeimbangkan semua fungsi motoriknya. Selain tubuhnya aktif, anak juga akan belajar mengkoordinasikan pancaindra melalui sentuhan, bau, rasa, pendengaran, dan penglihatan. Model pembelajaran Natural Messy Play bertujuan untuk meningkatkan kecerdasan kinestetik anak usia 4-5 tahun. Novelty dalam penelitian ini terletak pada sintaks pelaksanaan permainan yang dikemas dalam sebuah model pembelajaran. 


\section{METODOLOGI}

Penelitian ini menggunakan jenis research and development yang mengacu pada 10 langkah model penelitian pengembangan (Schratz, 2020) yang merupakan model penelitian yang digunakan untuk menghasilkan produk dan menguji keefektifan produk serta menjadi strategi penelitian yang cukup ampuh untuk memperbaiki praktek. Langkah penelitian pengembangan Borg \& Gall dapat dilihat pada Gambar 1 berikut ini.

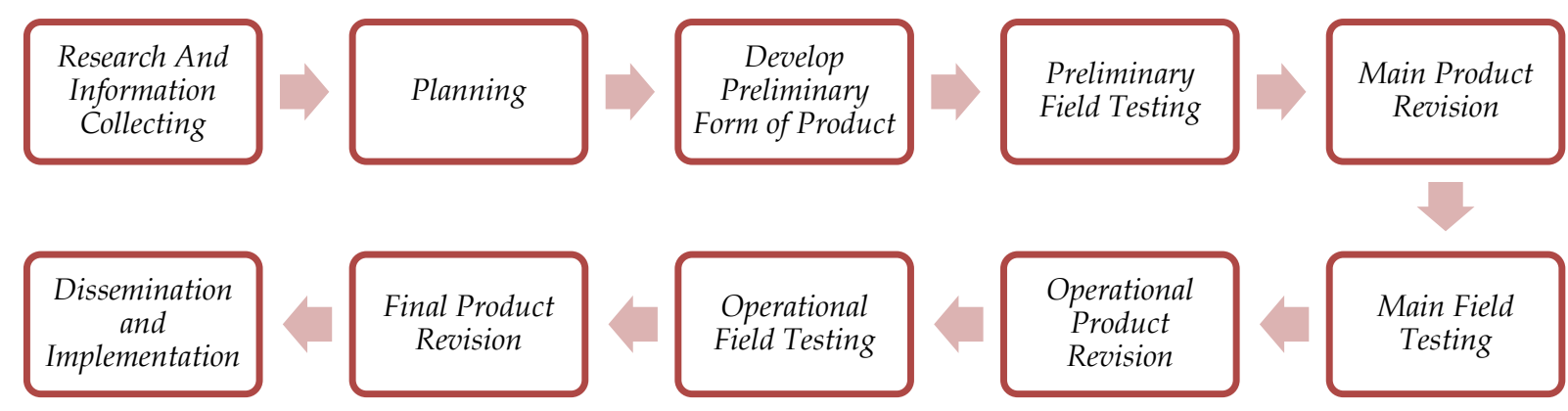

Gambar 1. Model Penelitian Pengembangan

(Schratz, 2020)

Produk yang dihasilkan berupa model pembelajaran Natural Messy Play untuk meningkatkan kecerdasan kinestetik pada anak usia 4-5 tahun di Kabupaten Sleman DIY. Waktu penelitian dilakukan selama 3 bulan. Subjek uji coba dalam penelitian ini adalah anak usia 4-5 tahun se-Kabupaten Sleman yang terdiri dari 10 subjek uji coba lapangan awal/terbatas, 35 subjek uji coba lapangan utama/diperluas, dan 75 subjek uji coba lapangan operasional. Pengumpulan data dilakukan dengan menggunakan teknik observasi, wawancara, dan angket dengan desain equivalent time series design.

Instrumen pengumpulan data yang digunakan berupa pedoman wawancara studi pendahuluan, pedoman observasi studi pendahuluan, angket validasi ahli, angket respon guru, pedoman observasi respon anak, dan pedoman observasi kecerdasan kinestetik. Uji kelayakan produk dilakukan oleh 2 validator yakni ahli materi dan ahli media pembelajaran. Kelayakan dari model pembelajaran Natural Messy Play dianalisis dengan mengkonversikan skor kedalam 5 kategori kuantitatif. Keefektifitasan model pembelajaran Natural Messy Play dianalisis menggunakan analisis statistik inferensial dengan melakukan uji Kruskal Wallis menggunakan SPSS dengan taraf signifikansi 0,05.

\section{HASIL DAN PEMBAHASAN}

Kecerdasan kinestetik dalam penelitian ini terdiri dari 6 aspek yang akan dinilai perkembangannya yakni aspek koordinasi, kekuatan, kecepatan, kelincahan, keseimbangan, dan kontrol gerak. Keenam aspek tersebut tervisualisasikan dalam rangkaian kegiatan pada model pembelajaran Natural Messy Play. Aktivitas dalam pelaksanaan model pembelajaran Natural Messy Play berupa berlari zig-zag sesuai pola, menempel bahan alam pada pola finger painting, berlari bolak-balik memindahkan benda, melukis dengan media bahan alam, berjalan diatas papan titian dan menjemur benda yang digunting sesuai pola.

Model pembelajaran Natural Messy Play merupakan pengembangan dari konsep bermain berantakan (Messy Play). Konsep dari permainan Natural Messy Play yang dikembangkan memiliki perbedaan dengan konsep Messy Play pada umumnya. Perbedaaan antara Model pembelajaran Natural Messy Play dengan Messy Play dapat dilihat pada tabel 1.

Natural Messy Play memiliki prinsip be dirty, be brave, be healthy with nature untuk meningkatkan kecerdasan kinestetik anak. Be dirty artinya model pembelajaran Natural Messy Play memberikan kebebasan kepada anak untuk bermain kotor dengan bahan alam. Be brave memiliki arti bahwa model pembelajaran Natural Messy Play mengajarkan anak untuk berani 
DOI: 10.31004/obsesi.v6i1.914

menggunakan permainan yang berada di lingkungan alam. Be healthy artinya model pembelajaran Natural Messy Play menjadikan anak sehat dengan bermain bersama alam. Skema konseptual model pembelajaran Natural Messy Play dapat dilihat pada gambar 2.

Tabel 1. Perbedaan Messy Play dan Natural Messy Play

\begin{tabular}{cll}
\hline Komponen & \multicolumn{1}{c}{ Messy Play } & \multicolumn{1}{c}{ Natural Messy Play } \\
\hline Sintaks & $\begin{array}{l}\text { Bermain bebas tanpa } \\
\text { aturan dan langkah- } \\
\text { langkah terstruktur }\end{array}$ & $\begin{array}{l}\text { 1. Menggunakan teknik sirkuit (terdiri dari 3 pos } \\
\text { berjalan dan 3 pos utama) }\end{array}$ \\
& & $\begin{array}{l}\text { 2. Anak harus menyelesaikan semua kegiatan yang } \\
\text { terdapat dalam masing-masing pos } \\
\text { 3. Dalam setiap pos harus terdapat aktivitas motorik } \\
\text { halus dan motorik kasar }\end{array}$ \\
& & $\begin{array}{l}\text { 4. Kegiatan pembelajaran selesai jika anak sudah } \\
\text { menyelesaikan semua pos }\end{array}$ \\
& & $\begin{array}{l}\text { Kegiatan pembelajaran dilakukan secara kelompok } \\
\text { yang terdiri dari 3-5 anak }\end{array}$ \\
Social & Bermain individual & 1. Lingkungan alam \\
system & Material bahan apapun & 2. Material bahan alam (karet gelang, pewarna \\
system & yang dapanan, beras, air dengan berbagai warna, cat \\
& anak berantakan (pasir, & poster, dan biji-bijian/kacang-kacangan, bola, jepit \\
& tepung, air, busa, jelly, & jemuran dan corong plastik) \\
& dll). & 3. Buku panduan \\
& & 4. Video pelaksanan \\
\hline Peran guru & 1. Pengamat & 1. Fasilitator \\
& 2. Fasilitator & 2. Pengamat \\
& & 3. Pembimbing \\
& 4. Evaluator \\
\hline
\end{tabular}

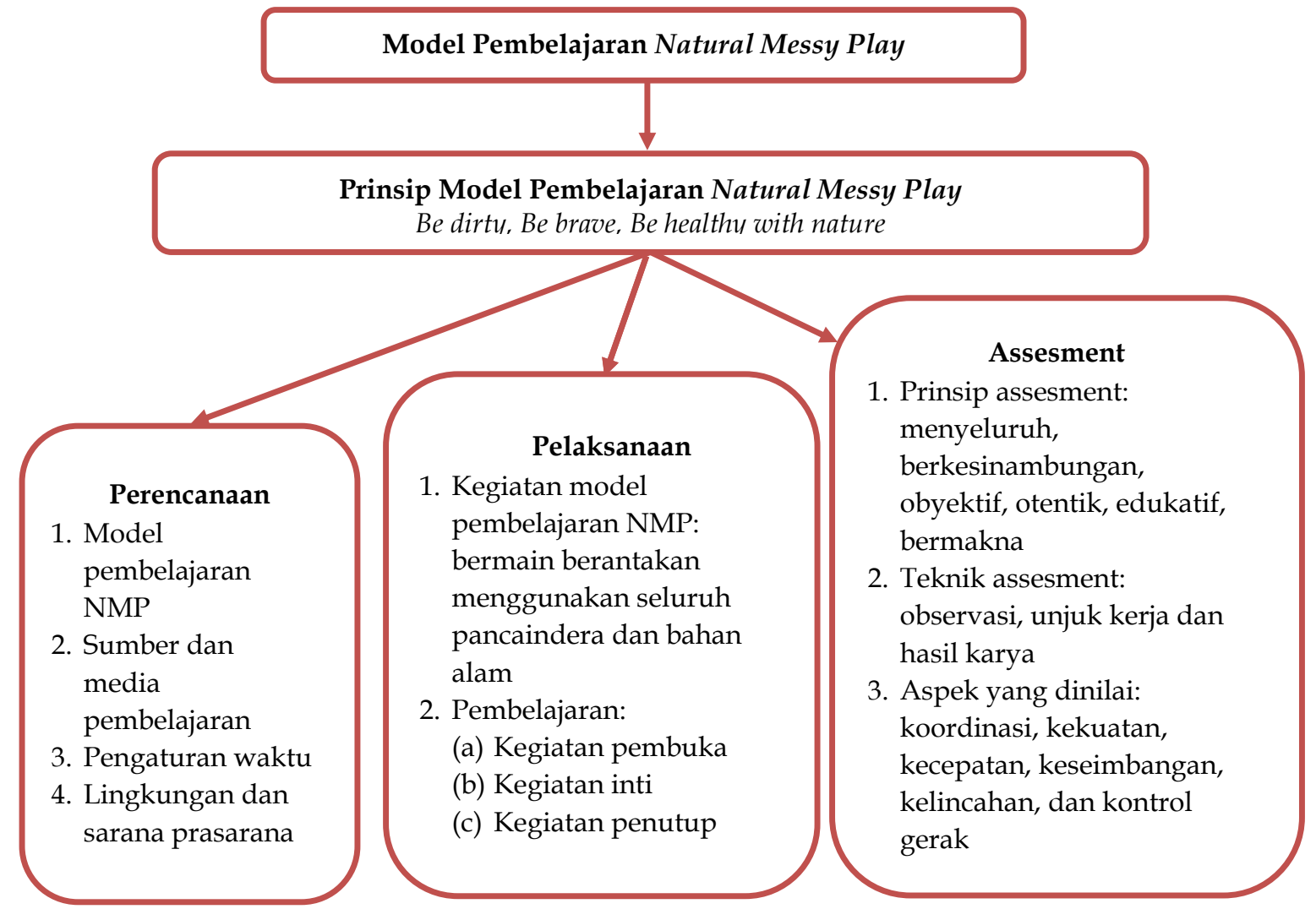

Gambar 2. Skema Konseptual Model Pembelajaran Natural Messy Play 
Setelah produk berupa model pembelajaran Natural Messy Play lengkap dengan buku panduan dan video pelaksanaan dirancang, langkah selanjutnya adalah meguji validitas dan reliabilitas dari model pembelajaran tersebut. Validasi model pembelajaran dilakukan dengan melibatkan 2 validator yakni ahli materi (menilai materi dan instrumen) dan ahli media. Sedangkan reliabilitas instrumen kecerdasan kinestetik anak dilakukan dengan melibatkan 5 orang rather yang terdiri dari 4 oranag guru dan 1 dosen ahli materi. Reliabilitas instrumen dalam penelitian ini diuji menggunakan metode Alpha Cronbach's. Nunnally dalam (Annisa, dan Sutapa, 2019) mensyaratkan suatu instrumen dikatakan reliabel jika memiliki koefisien Cronbach Alpha di atas 0,60. Perhitungan uji reabilitas alpha dalam penelitian ini dilakukan menggunakan SPSS 22.0. Hasil uji reliabilitas statistik dapat dilihat pada tabel 2.

Tabel 2. Hasil Reliabilitas Statistik

\begin{tabular}{|c|c|}
\hline Cronbach's Alpha & N of Items \\
\hline, 691 & 10 \\
\hline
\end{tabular}

Uji reliabilitas Alpha Cronbach's menunjukkan bahwa hasil uji reliabilitas sebesar 0,691. Sesuai dengan asumsi uji Alpha Cronbach's dengan reliabilitas minimal 0,60 maka instrumen kecerdasan kinestetik dinyatakan reliabel. Penelitian ini menggunakan 6 kali treatment dengan model pembelajaran Natural Messy Play. Pada setiap treatment dilakukan kegiatan yang sama dengan material dan tingkat kerumitan yang berbeda. Rekapitulasi hasil perbandingan rerata dan persentase akhir dari perkembangan kecerdasan kinestetik menunjukkan bahwa terjadi peningkatan skor dan persentase rerata mulai dari treatment 1 hingga treatment 6 . Jumlah peningkatan persentase rerata pada perkembangan kecerdasan kinestetik anak dapat dilihat pada grafik 1 .

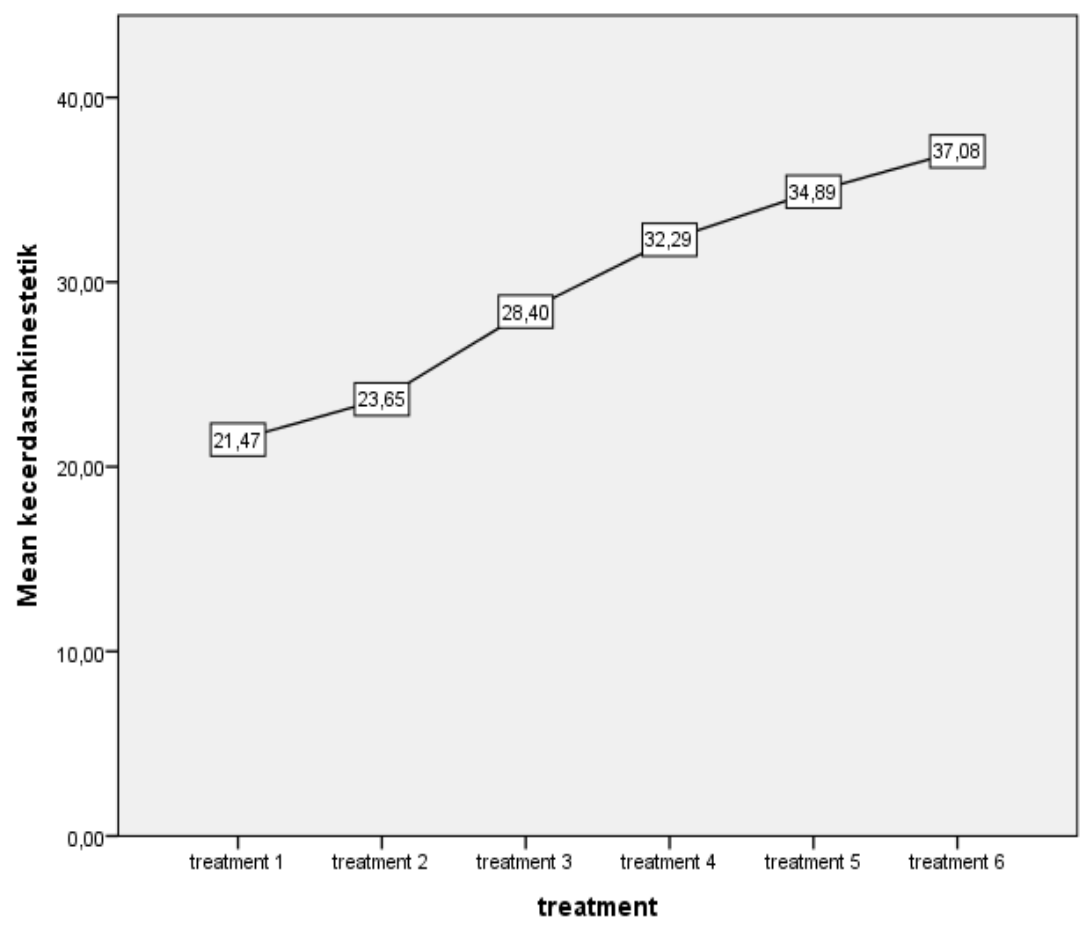

Grafik 1. Time Series Rerata Seluruh Aspek Kecerdasan Kinestetik

Setelah dijabarkan hasil rerata semua aspek dari 6 treatment, selanjutnya dianaslisis menggunakan SPSS 22.0. Analisis menggunakan SPSS 22.0 dilakukan untuk melihat adakah perbedaan peringkat rerata dari setiap treatment yang dilakukan menggunakan model pembelajaran Natural Messy Play. Setelah itu ditemukan nilai signifikansi untuk kemudian 
dibandingkan dengan asumsi uji Kruskal Wallis sehingga memperoleh kesimpulan. Hasil uji statistik Kruskal Wallis dapat dilihat pada tabel 3.

Berdasarkan data yang diperoleh, ditemukan Sign. sebesar 0,000 yang berarti $p<0,05$. Dapat disimpulkan bahwa Ha diterima dan Ho ditolak. Hal ini berarti terdapat perbedaan yang signifikan pada peringkat rerata kecerdasan kinestetik anak menggunakan model pembelajaran Natural Messy Play. Dengan demikian, dapat digeneralisasikan bahwa penggunaan Model pembelajaran Natural Messy Play dapat meningkatkan kecerdasan kinestetik anak usia 4-5 tahun.

Tabel 3. Hasil Uji Statistik Kecerdasan Kinestetik

\begin{tabular}{lr}
\multicolumn{2}{c}{ Test Statistics $^{\mathbf{a}, \mathbf{b}}$} \\
\hline \multicolumn{2}{c}{ Kecerdasan kinestetik $^{2}$} \\
\hline Chi-Square & 355,409 \\
Df & 5 \\
Asymp. Sig. &, 000 \\
\hline
\end{tabular}
a. Kruskal Wallis Test
b. Grouping Variable: treatment

Dalam hal pengembangan sebuah model pembelajaran, peran guru merupakan salah satu hal yang sangat penting untuk mendukung berlangsungnya proses pembelajaran. Guru harus mampu mengembangkan berbagai metode pembelajaran, berbagai macam sumber dan bahan ajar, serta interaksi dan komunikasi yang beragam bagi anak (Maharani et al., 2020). Oleh karena itu, dibutuhkan media pembelajaran sebagai alat pendukung tersampaikannya pesan dari guru kepada anak.

Model pembelajaran Natural Messy Play menggunakan media pendukung yakni buku panduan dan video pelaksanaan. Sebelum digunakan sebagai media pendukung dalam pelaksanaan model pembelajaran Natural Messy Play, maka buku panduan beserta video pelaksanaan harus melalui tahap validasi yang dilakukan oleh ahli media. (Zaman et al., 2010) menyatakan bahwa media pembelajaran harus memiliki 3 ciri yaitu ciri fiksatif, ciri manipulatif, dan ciri distributif.

Ciri fiksatif berarti media dapat menangkap, menyimpan dan merekomendasikan suatu objek atau peristiwa yang telah terjadi di masa lampau. Ciri manipulatif berarti media dapat mengubah objek waktu dan peristiwa. Sedangkan ciri distributif beraryi media dapat menyajikan suatu peristiwa dalam radius yang luas. Dalam penelitian ini, material bahan alam menjadi icon utama dan terpenting yang harus ada dalam pelaksanaan model pembelajaran Natural Messy Play.

Efektivitas model pembelajaran Natural Messy Play dipandang dari 6 aspek pendukung kecerdasan kinestetik yakni aspek koordinasi, kekuatan, keseimbangan, kecepatan, kelincahan, dan kontrol gerak. Pentingnya koordinasi pada anak juga berkaitan dengan penyebab obesitas di usia dini. Hal ini didukung oleh pendapat (Han et al., 2018) yang menyatakan bahwa mengembangkan keterampilan motorik dan koordinasi di masa kecil dapat membantu memecahkan lingkaran setan untuk mengurangi obesitas di masa kecil.

Faktor jenis kelamin juga mempengaruhi koordinasi motorik pada anak. Anak-anak yang kelebihan berat badan dan obesitas dari kedua jenis kelamin menunjukkan koordinasi motorik yang jauh lebih rendah dari pada anak-anak yang memiliki berat badan normal (Lopes et al., 2012). Diasumsikan bahwa jumlah aktivitas fisik yang lebih besar atau tindak lanjut yang lebih panjang mungkin diperlukan untuk mendorong perubahan lemak tubuh pada usia muda (Bürgi et al., 2011).

Tes kebugaran fisik dapat digunakan untuk mengevaluasi status kebugaran anakanak, mengembangkan program yang dipersonalisasi, melacak kemajuan, memotivasi peserta, dan mempromosikan pendidikan jasmani (Milliken \& Faigenbaum, Avery D; Loud, Rita LaRosa; Westcott, 2008). Melompat dan meloncat merupakan aktivitas motorik kasar 
yang mengharuskan anak untuk menggunakan otot besar yang dapat digunakan untu menguji kebugaran fisik anak.

Kegiatan mengambil dan memindahkan bola juga berpengaruh terhadap pernafasan dan fungsi jantung anak. Dengan berlari, jantung akan lebih cepat memompa darah ke seluruh tubuh sehingga tubuh anak menjadi segar dan tidak mudah sakit. Osifikasi tulang, pertumbuhan dan pematangan sistem saraf pusat adalah dianggap sebagai faktor yang relevan mengenai kiprah kecepatan individu (Müller et al., 2013).

Berlari bolak-balik dengan jarak 3 meter merupakan salah satu aktivitas dalam model pembelajaran Natural Messy Play yang dapat menstimulasi kemampuan kecepatan anak dalam mengolah tubuh. Evolusi motorik dengan instruksi verbal berbeda sesuai usia. Peningkatan antara kecepatan dan akurasi kondisinya akan meningkat dengan bertambahnya usia (Rival et al., 2003).

Dalam melakukan aktivitas gerak, tentunya anakn membutuhkan kekuatan dari dalam tubuhnya. Kekuatan terjadi karena perkembangan gerakan kaki depan yang terampil, tetapi tidak meningkatkan kekuatan kaki depan, dikaitkan dengan reorganisasi representasi gerakan kaki depan dalam korteks motorik (Sugden, 1980). Peningkatan kemampuan pada aspek kekuatan yang terjadi pada anak memiliki beberapa penyebab. Stimulasi berupa aktivitas yang dilakukan dalam model pembelajaran Natural Messy Play merupakan alasan utama terjadinya peningkatan kemampuan anak.

Berjalan diatas papan titian merupakan aktivitas yang melibatkan keseimbangan anak dalam model pembelajaran Natural Messy Play. Keseimbangan fungsional pada anak-anak didefinisikan sebagai kemampuan untuk mempertahankan pusat massa sehubungan dengan basis dukungan selama kegiatan masa kanak-kanak yang khas dari kehidupan sehari-hari di sekolah seperti bermain (Biedry \& Cech, 2010). Keseimbangan dikatakan berhasil jika langkahlangkah sukses secara berturut-turut diatas balok dihitung sampai kaki anak menyentuh lantai/tanah. Anak-anak dapat mencapai maksimal delapan langkah (Bürgi et al., 2011).

Kontrol gerak berkaitan dengan gerakan refleks anak sehingga muncul inisiatif untuk melakukan aktivitas gerakan. Kegigihan refleks primitif dapat mengubah lintasan perkembangan kemampuan motorik masa depan (Chinello et al., 2018). Sesuai dengan karakterikstik kecerdasan kinestetik anak bahwa anak yang memiliki kecerdasan kinestetik tidak mampu bertahan lama tanpa melakukan aktivitas gerak tubuh. Semakin sering anak bergerak dan melakukan aktivitas fisik, maka semakin baik kecerdasan kinestetiknya. Kemampuan anak dalam mengontrol gerakan dapat dilihat pada aktivitas anak sehari-hari baik itu di rumah maupun di sekolah.

Aktivitas yang dilakukan untuk menstimulasi kemampuan anak mengontrol gerakan dengan melakukan rangkaian kemampuan gerak dasar sederhana seperti meminta anak untuk piket seperti membuka dan menutup pintu, membagikan makanan kepada temantemannya, memimpin kelas hingga membersihkan papan tulis (Iivonen \& Sääkslahti, 2014). Dalam hal ini yang diperhatikan adalah seberapa besar inisiatif anak dalam melakukan aktivitas diluar daripada tugas wajibnya. Kontrol gerak terhadap gerakan juga berkaitan dengan gerak refleks pada diri anak.

Melalui rangkaian aktivitas yang ada dalam model pembelajaran Natural Messy Play dapat melatih ketelitian, kesabaran pada anak, serta memberikan pengalaman bermain sekaligus belajar melibatkan alam (Nugraha et al., 2019). Aktivitas menggunakan seluruh tubuh yang menyenangkan dalam rangkaian model pembelajaran Natural Messy Play membiasakan anak bermain dilingkungan outdoor dengan material yang menyebabkan anak menjadi berantakan dan tidak takut kotor. Keberanian dalam diri anak juga akan meningkat seiring dengan aktifnya anak bermain dilingkungan alam (Annisa, 2018). Hal ini baik untuk anak dalam menghadapi tantangan hidup di abad 21 yang mengharuskan anak memiliki keterampilan hidup untuk mampu memecahkan masalah dengan baik dan meningkatkan kecerdasan kinestetik anak usia 4-5 tahun secara optimal. 


\section{SIMPULAN}

Penggunaan material bahan alam dan aktivitas kinestetik di lingkungan alam menjadi sebuah cara yang efektif untuk mengoptimalisasikan kecerdasan kinestetik anak usia 4-5 tahun se-Kabupaten Sleman. Aktivitas yang terangkum dalam sebuah model pembelajaran Natural Messy Play menjadi pengalihan perhatian anak dari gadget sehingga dapat mengurangi dampak negatif penggunaannya. Model pembelajaran Natural Messy Play menghasilkan perbedaan yang signifikan pada peringkat rerata kecerdasan kinestetik anak berdasarkan hasil uji statistik Kruskal Wallis (taraf sig. < 0,05) yang memperoleh nilai sig. 0,00. Pemanfaatan model pembelajaran Natural Messy Play ini dapat dilanjutkan pelaksanaannya di lingkungan rumah dengan mengkaji aspek perkembangan sosial emosional anak.

\section{UCAPAN TERIMA KASIH}

Terimakasih yang sebesar-besarnya saya ucapkan untuk PAUD se-Kabupaten Sleman yang bersedia memberikan izin untuk digunakan sebagai lokasi penelitian, teruntuk pembimbing terbaik saya dalam penyelesaian penelitian ini Dr. Panggung sutapa M.Si, dan kedua orangtua dan sahabat yang mendukung secara materi dan moral.

\section{DAFTAR PUSTAKA}

Annisa, Aulia dan Sutapa, P. (2019). Pengembangan Model Pembelajaran Natural Messy Play untuk Meningkatkan Kecerdasan Kinestetik Anak Usia 4-5 Tahun [Universitas Negeri Yogyakarta]. http://eprints.uny.ac.id/id/eprint/65541

Annisa, A. (2018). Implementation of Messy Play To Improve Early Childhood ' S Intrapersonal Intelligence. Proceeding of International Conference On Child-Friendly Education, 80-85.

Annisa, A., \& Sutapa, P. (2019). The Implementation of Nature-based Learning Models to Improve Children's Motor Skills. Jurnal Obsesi : Jurnal Pendidikan Anak Usia Dini, 3(1), 170. https://doi.org/10.31004/obsesi.v3i1.140

Armstrong, T. (2009). Multiple intelligencies in the classroom. USA: Ascd.

Astuti Ria. (2017). Pendidikan anak usia dini berwawasan bilingual dan tauhid (studi kasus di paud. Universitas Islam Negeri Sunan Kalijaga, Yogyakarta.

Biedry, N. L., \& Cech, D. J. (2010). Commentary on motor proficiency in children with neurofibromatosis type 1. Pediatric Physical Therapy, 22(4), 349. https://doi.org/10.1097/PEP.0b013e3181fab948

Blumenfeld-Jones, D. (2009). Bodily-kinesthetic intelligence and dance education: Critique, revision, and potentials for the democratic ideal. Journal of Aesthetic Education, 43(1), 5976. https://doi.org/10.1353/jae.0.0029

Bürgi, F., Meyer, U., Granacher, U., Schindler, C., Marques-Vidal, P., Kriemler, S., \& Puder, J. J. (2011). Relationship of physical activity with motor skills, aerobic fitness and body fat in preschool children: A cross-sectional and longitudinal study (Ballabeina). International Journal of Obesity, 35(7), 937-944. https://doi.org/10.1038/ijo.2011.54

Castetbon, K., \& Andreyeva, T. (2012). Obesity and motor skills among 4 to 6 -year-old children in the united states: Nationally-representative surveys. BMC Pediatrics, 12. https://doi.org/10.1186/1471-2431-12-28

Charles, C., \& Louv, R. (2009). Children's Nature Deficit: What We Know - and Don't Know. Children \& Nature Network, September, 1-32.

Chinello, A., Di Gangi, V., \& Valenza, E. (2018). Persistent primary reflexes affect motor acts: Potential implications for autism spectrum disorder. Research in Developmental Disabilities, 83, 287-295. https:// doi.org/10.1016/j.ridd.2016.07.010

Damovska, L., Shehu, F., Janeva, N., Palcevska, S., \& Panova, L. S. (2009). Early Childhood Development: Early Learning and Development Standards for Children From 0-6 Years. https://www.unicef.org/tfyrmacedonia/MK_Pub_ELDS_ENG.pdf

Han, A., Fu, A., Cobley, S., \& Sanders, R. H. (2018). Effectiveness of exercise intervention on improving fundamental movement skills and motor coordination in overweight/obese children and adolescents: A systematic review. In Journal of Science and Medicine in Sport 
Pengembangan Model Pembelajaran Natural Messy Play sebagai Optimalisasi Kecerdasan Kinestetik Anak DOI: 10.31004/obsesi.v6i1.914

(Vol. 21， Issue 1, pp. 89-102). Sports Medicine Australia. https://doi.org/10.1016/i.jsams.2017.07.001

Hinkley, T., Salmon, J., Okely, A. D., \& Trost, S. G. (2010). Correlates of sedentary behaviours in preschool children: a review. In International Journal of Behavioral Nutrition and Physical Activity (Vol. 7, pp. 1-10). https://doi.org/10.1186/1479-5868-7-66

Iivonen, S., \& Sääkslahti, A. K. (2014). Preschool children's fundamental motor skills: A review of significant determinants. In Early Child Development and Care (Vol. 184, Issue 7, pp. 11071126). Taylor \& Francis. https:// doi.org/10.1080/03004430.2013.837897

Kellert, S. R. (2018). Nature in buildings and health design. In Oxford Textbook of Nature and Public Health (pp. 247-251). Oxford University Press. https://doi.org/10.1093/med/9780198725916.003.0015

Kivunja, C. (2015). Creative Engagement of Digital Learners with Gardner's Bodily-Kinesthetic Intelligence to Enhance Their Critical Thinking. Creative Education, 06(06), 612-622. https://doi.org/10.4236/ce.2015.66060

Kutz, M., Dyer, S., \& Campbell, B. (2013). Multiple Intelligence Profiles of Athletic Training Students. Internet.Journal of Allied Health Sciences \& Practice, 11(1), 9p. http:// search.ebscohost.com/login. aspx?direct=true\&db=cin20\&AN=2011937192\&site $=\mathrm{e}$ host-live

Lopes, V. P., Stodden, D. F., Bianchi, M. M., Maia, J. A. R., \& Rodrigues, L. P. (2012). Correlation between BMI and motor coordination in children. Journal of Science and Medicine in Sport, 15(1), 38-43. https://doi.org/10.1016/i.jsams.2011.07.005

Maharani, R., Marsigit, M., \& Wijaya, A. (2020). Collaborative learning with scientific approach and multiple intelligence: Its impact toward math learning achievement. Journal of Educational Research, 113(4), 303-316. https:// doi.org/10.1080/00220671.2020.1806196

Milliken, L. A., \& Faigenbaum, Avery D; Loud, Rita LaRosa; Westcott, W. L. (2008). C u 1 b m s c. $\begin{array}{llll}\text { Strength and } \quad \text { Conditioning } & \text { 1339-1346. }\end{array}$ https://doi.org/10.1519/JSC.0b013e31817393b1

Müller, J., Müller, S., Baur, H., \& Mayer, F. (2013). Intra-individual gait speed variability in healthy children aged 1-15 years. Gait and Posture, 38(4), 631-636. https://doi.org/10.1016/j.gaitpost.2013.02.011

Nugraha, A., Sukoco, P., \& Annisa, A. (2019). Motivation and Physical Education Learning Achievement among Students with Hearing Impairment. Acta Facultatis Educationis Physicae Universitatis Comenianae, 59(2), 129-137. https://doi.org/10.2478/afepuc-2019$\underline{0011}$

Rival, C., Olivier, I., \& Ceyte, H. (2003). Effects of temporal and/or spatial instructions on the speed-accuracy trade-off of pointing movements in children. Neuroscience Letters, 336(1), 65-69. https:// doi.org/10.1016/S0304-3940(02)01246-6

Schratz, M. (2020). Voices in Educational Research: An Introduction. In Qualitative Voices in Educational Research (pp. 1-6). https://doi.org/10.4324/9781003008064-1

Sudijandoko, A. (2011). Peningkatan kinerja pendidik paud dalam pengembangan kemampuan kinestetik. Jurnal Cakrawala Pendidikan, 91-102.

Sugden, D. A. (1980). Movement speed in children. Journal of Motor Behavior, 12(2), 125-132. https://doi.org/10.1080/00222895.1980.10735212

Szekely, I. (2015). Playground Innovations and Art Teaching. Art Education, 68(1), 37-42. https:// doi.org/10.1080/00043125.2015.11519304

Widhianawati, N. (2011). Pengaruh pembelajaran gerak dan lagu dalam meningkatkan kecerdasan musikal dan kecerdasan kinestetika anak usia dini. Inovete,(2), 2(Edisi Khusus), 220-228.

Yin, L.C; Zakaria, A.R; Sulaiman, A. . (2017). Social interactions and networking in cyber society. Social Interactions and Networking in Cyber Society, 1-247. https://doi.org/10.1007/978981-10-4190-7

Zaman, B., Pd, M., \& Eliyawati, H. C. (2010). Media Pembelajaran Anak Usia Dini. In Media Pembelajaran Anak Usia Dini (p. 34). Jakad Media Publishing. http://file.upi.edu/direktori/fip/jur._pgtk/197010221998022cucu_eliyawati/media_pembelajaran_anak_usia_dini-ppg_upi.pdf 